\title{
MASIFIKASI WACANA SYARIAH SEBAGAI IDENTITAS KE-ISLAMAN
}

\author{
ABDUL RAHIM \\ Email : abdulrahim09bi@gmail.com
}

\begin{abstract}
Abstrak
Tulisan ini mencoba menguraikan wacana syariah yang digaungkan oleh Dewan Syariah Nasional sebagai solusi ideal dalam produk/program yang sesuai dalam hukum Islam, akan tetapi pada praktiknya justru menjadi selubung dominasi yang diterima oleh masyarakat muslim sebagai sesuatu yang taken for granted. Wacana syariah sekedar menjadi identitas atas produk/program yang dilegitimasi oleh pemilik kuasa. Praktik wacana syariah yang menciptakan kapitalisme baru terjadi pada Bank syariah, BPJS syariah, dan Koperasi Syariah. Relasi kuasa dari Dewan Syariah Nasional yang menjejalkan wacana syariah sebagai konsep yang ideal, dibaliknya terdapat kepentingan kapitalis yang berjejaring dengan produk/program Non-syariah (konvensional). Melalui kuasa DSN sebagai pihak yang memiliki pengetahuan, masyarakat muslim sebagai sasaran mulai terhegemoni atas wacana syariah tersebut, sebab kultus kepada DSN yang merepresentasikan pihak intelektual dalam hukum Islam. Sementara praktik konsumtif dalam wacana syariah tersebut terlihat pada konsep wisata syariah, hotel syariah, dan hijab syar'i. Hijab syar'i yang menjadikan produk fashion menjadi booming, semakin mendukung eksistensi kapitalisme dalam memediasi kebutuhan ekspresif perempuan muslim akan identitas kesalihan, kecantikan dan ke-feminim-an. Hijab syar'i yang menjadi andalan kapitalisme dalam produk fashion yang menyasar masyarakat muslim, membentuk konsumerisme yang berlebihan dalam berhias (tabarruj) dari pada kesederhanaan yang diidealkan dalam syariat Islam. Praktik syariah yang ideal dan sesuai dengan hukum Islam dalam hal ekonomi bisa digaungkan kembali melalui maksimalnya tata kelola BaitulMal sebagai wadah akomodatif untuk ZakatMal, Infaq, wakaf dan lainnya. Sehingga syariah bukan lagi sekedar identitas dan praktik industri budaya islami, namun sesuai dengan hukum Islamyang semestinya.
\end{abstract}

Kata Kunci : Wacana Syariah, Dominasi, Identitas, konsumerisme.

\section{A. Pendahuluan}

Wacana syariah yang berkembang di Indonesia sekarang ini lebih mengarah pada politik identitas untuk menunjukkan bahwa lini kehidupan masyarakat muslim yang mau dibawa kembali kepada syariat Islam, mempunyai peluang 
untuk dilakukan. Dimulai dengan kemunculan studi tentang ekonomi Islam yang ditawarkan di perguruan tinggi, lalu wacana syariah mulai berkembang dengan diadakannya produk syariah yang dihajatkan sebagai resistensi dari produk konvensional. Produk konvesional tersebut menurut Dewan Syariah Nasional (DSN) dirasa tidak sejalan dengan nilai Islammaupun nilai sosial masyarakat yang berlaku, maka produk syariah dihajatkan sebagai solusi untuk perubahan sistem tersebut.

Definisi Syariah (dalam Islam.wiki.co.id, 2012) secara etimologi berarti peraturan/jalan, sedangkan dalam terminologi Islam dipahami sebagai hukum yang sesuai dengan tuntunan Allah SWT. dalam kitab suci (Al Qur'an) dan Hadits Rasulullah sebagai penjelasan dari kitab suci tersebut, baik dalam urusan duniawi (Fiqh Muamalah) maupun yang bersifat Ukhrawi (Fiqh Ibadah, Tasawwuf). Syariah yang digaungkan dalam terminologi Islam ini sebenarnya emansipatoris untuk membawa masyarakat muslim untuk kembali kepada hukum dalam Islam yang dicontohkan ketika zaman Rasulullah, Sahabat dan zaman ulama-ulama yang mengikuti beliau (Thabi'in, Thabi'ut Thabi'in). Syariah dalam hukum Fiqh lebih ditegaskan menjurus kepada persoalan Ukhrawi dalam tata laku masyarakat sehari-hari, dan juga ibadah amaliah, yang dirancang pada masyarakat muslim mayoritas, seperti halnya Peraturan Daerah (Perda) Syariah di Aceh.

Akan tetapi wacana syariah yang berkembang dalam skala Nasional sekarang ini lebih mengarah ke urusan duniawi yang disamarkan melalui kuasa Dewan Syariah Nasionaluntuk memasukkan inisial syariah sebagai sebuah identitas produk/program sesuai dengan hukum Islam. Masyarakat muslim sebagai subjek sasaran, dengan wacana syariah yang dikeluarkan sebagai langkah solusif dalam menjalankan program/produk yang sesuai dengan hukum Islam mulai terhegemoni dengan wacana tersebut.

Melalui kuasa dari Dewan Syariah Nasional maupun MUI yang memfatwakan bahwa produk konvensional bisa menjurus pada keharaman dengan konsep kapitalisme yang memeras masyarakat. Lalu ditawarkanlah produk syariah yang diwacanakan lebih sesuai dengan hukum Islam, meskipun pada praktiknya tidak jauh berbeda dengan produk yang sudah ada (konvensional) tersebut. Contoh produk/program syariah yang mulai berkembang diantaranya Bank Syariah, Koperasi Syariah, BPJS Syariah, Hotel Syariah, Wisata Halal/ Wisata Syariah, dan Hijab Syar'i. 


\section{B. RUMUSAN MASALAH}

Dalam tulisan ini penulis mencoba menguraikan rumusan masalah bagaimana wacana syariah yang berkembang saat ini menjadikan kuasa dari Dewan syariah nasional untuk mendominasi masyarakat muslim agar menerima konsep syariah sebagai sesuatu yang ideal, sementara pada praktiknya jauh dari nilai dalam hukum Islam dan nilai kemanusiaan. Bahkan menciptakan kapitalisme baru dalam jaringan kapitalisme yang sudah mapan/langgeng. Selain itu penulis juga akan menguraikan bagaimana konsep syariah yang digaungkan tersebut menjadi nilai kepatuhan dalam beragama sebagai politik identitas, serta wacana syariah sebagai industri budaya islami dalam promosi produk/program syariah.

\section{KERANGKA TEORI}

Ditinjau dari persfektif Foucault (2002) aspek kuasa dari Dewan Syariah Nasional yang mendominasi melalui wacana Syariah yang digaungkan, sekedar simbol untuk menjustifikasi suatu tindakan sesuai dengan hukum dalam Islam. Relasi kuasa dari Dewan Syariah Nasional dan MUI sebagai subjek yang memproduksi wacana tersebut, bisa diterima oleh masyarakat muslim dengan modalitas mereka yang dikultuskan sebagai pihak yang mempunyai pengetahuan. Lalu pengetahuan mereka dalam hal hukum Islam dituangkan untuk menciptakan produk baru (syariah) yang disamarkan melalui selubung agama, dibalik hal tersebut terdapat kepentingan kapitalis/perusahaan yang sudah mapan sebagai penyokong produk syariah tersebut. Sementara dalam praktiknya bisa dikatakan tidak sesuai dengan konsepsi syariah (Hukum) dalam Islam.

Syariah sebagai wacana yang diproduksi oleh pihak yang memiliki kuasa digunakan untuk menggiring opini masyarakat dengan rasionalitas yang dijejalkan sesuai dengan tuntunan agama, dan mencoba membuat subjek diklaim religius ketika mau beralih ke konsepsi syariah tersebut. Syariah jika dikaitkan dengan dialektika pencerahannya Adorno- Horkheimer (2002) dianalogikan sebagai rasionalitas untuk mengembalikan markah masyarakat muslim kepada tuntunan agama, akan tetapi dalam praktiknya justru menimbulkan kapitalisme baru dalam masyarakat itu sendiri. Praktik-praktik produk syariah yang diklaim sebagai pencerahan menimbulkan penindasan baru dan kerenggangan sosial, seperti halnya dalam praktik Bank Syariah dan Wisata Syariah yang diwacanakan.

Sedangkan Syariah ditinjau dari konsep Ideological State Aparatus (ISA) yang dikemukakan Althusser, yaitu institusi agama, kebudayaan, pendidikan, 
termasuk media massa turut membentuk ideologi masyarakat agar menerima konsep yang diwacanakan oleh pihak yang mempunyai kuasa sebagai bentuk kepatuhan. Cara kerja ISA lebih banyak bergerak pada aspek idiologis, kemudian pada akhirnya akan bersifat represif juga, karena memang dimaksudkan untuk memanipulasi kesadaran (dalam Halimatusa'diah 2014). Kesadaran masyarakat atas kepatuhan dalam agama menerima konsep syariah sebagai solusi, akan tetapi tersembunyi selubung agama sebagai politik di baliknya.

Bertalian dengan hal tersebut, pemikiran Althusser juga memperkuat pemikiran teoritisi Jerman, Antonio Gramsci (1971) mengenai hegemoni. Teori hegemoni Gramsci (1971), sebagaimana teori Ideological State Apparatus Althusser, pada dasarnya juga merupakan represi kekuasaan. Bedanya, represi dalam hegemoni itu berciri "halus" (subtle) mengandalkan kepemimpinan moral serta intelektual dan bersifat aktif. Hegemoni tidak dicapai melalui kekuatan koersif, tetapi melalui diskursus sistemik (bahasa), terarah, dan berkelanjutan untuk memenangkan penerimaan publik secara sukarela akan sebuah gagasan atau rezim (Barker, 2000: 61 dalam Halimatusa'diah 2014). Syariah yang di-hegemonikan oleh Dewan Syariah Nasional melalui institusi agama, pendidikan, media massa menjadi sebuah ideologi yang semakin mendukung kepentingan pemilik kuasa dibaliknya. Kepentingan-kepentingan ekonomi kapitalis semakin dilegitimasi atas penerimaan masyarakat yang dihegemoni secara halus melalui kepemimpinan moral dan intelektual dari Dewan Syariah Nasional tersebut.

\section{PRAKTIK WACANA SYARIAH SEBAGAI KAPITALISME BARU}

Salah satu contoh praktik produk Syariah yaitu Bank syariah, dengan bunga pinjaman yang lebih tinggi namun diselubungi dengan istilah "bagi hasil" (Sarwat 2013). Bank syariah yang dihajatkan sebagai solusi untuk mematahkan riba yang terjadi padabank-bank konvensional, justru dalam praktiknya Bank Syariah lebih tinggi bunga yang dipatok dengan klaim bagi hasil tadi. Bank syariah yang membantu pendanaan bagi usaha Individu atau kelompok yang meminjam pada mereka, sudah ditentukan di awal sekian Persennya yang akan menjadi bagian Bank, meskipun usaha dari individu yang meminjam tersebut belum juga berjalan.

Secara logika bank syariah mengabaikan aspek resiko yang bisa saja terjadi pada usaha si peminjam, sementara bunga untuk pengembalian sudah dipatok. Bunga dari pinjaman yang diklaim sebagai bagi hasil tidak menjanjikan program 
yang dijalankan oleh bank syariah sebagai solusi untuk sesuainya konsep ekonomi islam. Akan tetapi penindasan baru yang terjadi dengan selubung agama, seolah diterima masyarakat melalui kuasa dari DSN yang merepresentasikan intelektual muslim dan sebagai legitimasi atas halalnya produk/program yang ada. Bank syariah meski mengusung konsep ekonomi Islam akan tetapi dalam praktiknya justru lebih menindas dari pada bank konvensional, maka peran dari DSN dengan dalih untuk memperbesar ekonomi Islam dengan basis bank syariah menjadi sesuatu yang wajar, dengan masyarakat terhegemoni untuk berpartisipasi dalam pengembangannya.

Padahal jika kembali pada konsepsi syariah sebagai hukum Islam, bentuk bantuan dana tersebut jika disepakati sebagai bagi hasil, maka tidak ada ketentuan di awal untuk pembagian bagi penyedia dana dan pelaku usaha, jika terdapat keuntungan setelah usaha berjalan barulah ditentukan pembagian bagi hasil antara peminjam dan penyedia dana . Begitu juga ketika mengalami kerugian, penyedia dana tidak mendapat apa-apa, bahkan yang paling sesuai dimungkinkan penyedia dana membantu menanggung kerugian yang dialami pelaku usaha, inilah konsep syariah dan sesuai dengan nilai sosialisme dalam masyarakat.

Misi awal perbankan syariah yang dimaksudkan untuk membantu para pengusaha kecil dan lemah dalam modal ternyata tidak bisa terwujd sebagaimana yang diharapkan. Olehkarena itu tidaklah mengherankan bila kemudian muncul berbagai kritikan terhadapnya, baik darikalangan muslim sendiri maupun dari kalangan non-muslim. Sesuai dengan namanya, perbankan syariah seharusnya dapat memberikan kontribusi yang sangat signifikan bagi tujuan masyarakat muslim dalam bidang ekonomi, seperti pembebasankemiskinan, pendistribusian kekayaan secara adil, dan penciptaan lapangan kerja. Namun,menurut sebagian ahli, kontribusi yang maksimal tersebut terealisir jika ia dibiarkan beroprasi didalam kompetisi yang keras dengan bank-bank konvensional. Ia hanya mampu memberikanperannya yang positif secara penuh manakala praktek perbankan yang didasarkan atas bungasepenuhnya diganti dengan sistem keuangan islami (Niazi 1990, dalam Aziz 2012). Maka di sinilah terlihat bagaimana wacana syariah yang digaungkan dalam perbankan sebagai bentuk islamisasi yang artifisial.

Akan tetapi meskipun praktik Bank syariah terselubung dibaliknya kapitalisme/penindasan baru, namun masyarakat muslim yang dihegemoni dengan wacana syariah yang ada jaminan halal dari Dewan Syariah Nasional 
sebagai pemilik kuasa, maka hal tersebut diterima secara wajar saja. Lalu kultus kepada pihak DSN sebagai pihak yang memiliki pengetahuan tentang hukum, maka kuasa mereka atas wacana syariah itu pun mempunyai legitimasi untuk terus berlanjut. Relasi kuasa yang mereka miliki memproduksi wacana syariah sebagai selubung dominasi atas berbagai kepentingan dari pihak-pihak pemodal dalam Bank syariah yang berjejaring juga dengan Bank konvensional yang ada.

Begitu juga dengan praktik koperasi syariah, tidak jauh berbeda dengan konsep Bank syariah di atas. Koperasi konvensional yang mengelola unit simpanpinjam, dalam memberikan pinjaman kepada individu atau kelompok usaha, di awalnya ada kesepakatan atas bunga yang akan diberikan kepada pihak penyedia dana sebagai biaya operasional untuk kelangsungan koperasi. Koperasi syariah sama halnya dengan koperasi konvensional, hanya afiliasinya yang biasanya berada di bawah naungan institusi agama (Pondok pesantren, Perguruan tinggi Islam) diklaim lebih Islami dari koperasi konvensional, padahal praktiknya sama, dan syariah itu sebagai simbol atas selubung bunga yang mengindikasikan riba juga.

\section{E. SYARIAH SEBAGAI WACANA IDENTITAS}

Pesona Indonesia yang masih digaungkan saat ini mencoba mengusung wacana syariah juga dalam promosi wisatanya. Wisata halal/wisata syariah yang tahun 2015 lalu disematkan pada salah satu wilayah Indonesia yaitu Lombok sebagai wisata halal terbaik dan destinasi Honeymoon terbaik dari asosiasi wisata halal (Halal Tourism Association) dalam kompetisi World Halal Summit/Exhibition yang dipelopori oleh Uni Emirat Arab (travel.kompas.com, 2016), kembali digaungkan untuk tahun ini melalui vote-vote yang disebar di internet untuk memilih beberapa wilayah yang ditawarkan sebagai wisata halal terbaik.

Beberapa wilayah di Lombok yang akan dijadikan wisata syariah yaitu Masjid Islamic Center di Mataram, Pantai Pink yang ada di pedalaman Lombok Timur bagian selatan, dan Tanjung Bloam di Lombok Tengah. Wacana yang berkembang tentang wisata syariah yang ditawarkan pada masjid Islamic Center masih sebatas menampilkan kemegahan masjid, dan wacana NTB sebagai pusat studi Islam. Akan tetapi dua priode kepemimpinan Gubernur pengusungnya, masjid tersebut belum juga rampung, mengingat masa jabatannya yang akan berakhir pada 2017. 
Wisata syariah melalui Islamic Center yang berkembang pun mulai tercoreng dengan konsepsi syariah yang tidak benar-benar berlaku. Misalnya, beredarnya foto dua wisatawan asing yang sedang berciuman tepat di depan halaman Islamic Center, lalu beberapa waktu lalu menaranya dengan ketinggian 99 meter sempat menjadi arena wisata dengan pungutan liar agar dapat naik ke puncaknya untuk melihat sekeliling kota Mataram. Begitu juga pengunjung yang naik ke menara tersebut, banyak perempuan yang mengenakan celana pendek, baju lengan pendek dan berselfie di puncak menara tersebut.

Sedangkan wisata syariah (kabarlombok.com) yang dicanangkan di wilayah pantai, yaitu pantai Pink dengan keindahan pasir pantai yang berwarna merah muda dilihat dari kejauhan, dan aneka biota laut yang dapat dilihat langsung dengan kejernihan airnya. Pantai yang berada di wilayah administratif kabupaten Lombok Timur tersebut diwacanakan oleh Pemda Propinsi melalui Dinas Pariwisatanya untuk dijadikan objek wisata syariah dengan konsep wisata yang mengedepankan nilai Islami. Akan tetapi yang menjadi permasalahan dengan pengambil alihan daerah pantai tersebut sebagai area wisata yaitu penduduk di daerah tersebut yang sumber penghidupan sebagai nelayan, otomatis akan tersingkirkan dengan proteksi dari pemilik kuasa atas wilayah tersebut sebagai area wisata.

Kuasa Pemda melalui Peraturan Daerahnya (Perda) mulai menstandarisasi area wisata tersebut dengan standar akomodasi dan harga yang menjadi basis untuk pendapatan daerah. Lalu relasi antara pengunjung dan pihak pengelola wisata tersebut ditentukan oleh uang yang mereka miliki untuk bisa mengakses tempat wisata tersebut. Bahkan penduduk pribumi asli yang tempat tinggalnya berdekatan dengan area wisata tersebut, dengan standar harga yang ditentukan melalui kuasa Peraturan Daerah, mereka pun harus membayar untuk dapat menikmati wisata tersebut. Privatisasi area wisata dengan wacana syariah yang dikembangkan oleh pihak pemilik kuasa menjadikan penduduk aslinya tersingkirkan dari sumber penghasilan mereka, lalu akses wisata oleh penduduk sesama etnis Sasak pun harus membayar retribusi sesuai dengan standar yang ditentukan Pemerintah Daerah.

Lain halnya dengan konsep hotel syariah yang dikembangkan juga di Lombok. Melalui penghargaan sebagai wisata halal terbaik dan destinasi honeymoon terbaik yang didapatkan tahun lalu, Pemerintah daerah menawarkan kepada pengusaha hotel untuk mengubah konsep hotel mereka menjadi hotel 
syariah dengan pangsa pasar wisatawan muslim yang akan berkunjung. Beberapa hotel bersedia untuk konsep syariah tersebut, dengan ketentuan kejelasan identitas/status pengunjung, perluasan tempat ibadah, dekorasi dengan tampilan Islami, dan kuliner halal. Akan tetapi dalam praktiknya beberapa hotel yang menyetujui konsepsi syariah tersebut disebabkan pendapatan yang mulai menurun, secara sembunyi mulai berbalik arah untuk kelangsungan usaha mereka, namun label syariah tetap tersemat pada usahanya.

Salah satu dosen perguruan tinggi Islam di Mataram pernah melakukan studi kasus atas label syariah pada hotel tersebut apakah memang sesuai konsep syariah dalam hukum Islam. Kunjungannya ke salah satu hotel dengan label syariah tersebut diobservasi dengan menjadi pengunjung dan membawa salah seorang perempuan muda ke hotel tersebut. Ternyata di meja reservasi ketika dia memesan kamar tidak ditanyakan sama sekali status mereka apakah pasangan suami istri ataukah ada hubungan keluarga, pihak reservasi langsung memberikan kunci kamar kepada pengunjung, sebelumnya sekedar memeriksa identitas mereka (Wawancara dengan dosen Ekonomi Islam IAIN Mataram).

Konsep syariah pada hotel yang merujuk pada tawaran pemerintah daerah tersebut, menjadikan identitas syariah sebagai selubung atas persepsi masyarakat atas usaha yang mereka lakoni. Padahal praktik yang tidak sesuai dengan ketentuan tersebut seharusnya ada sanksi yang ditetapkan. Akan tetapi selubung tersebut seolah mendapat perlindungan juga atas usaha mereka dengan pajak dari operasional yang masuk sebagai pendapatan daerah. Konsep syariah yang diusung hotel tersebut merupakan upaya untuk menyamarkan bobrok yang terdapat dalam usaha mereka, dan kelangsungan usaha adalah hal penting yang harus dipertahankan. Konstruksi syariah sebagai identitas yang didukung oleh pemilik kuasa semakin mendukung eksistensi kapitalisnya.

Sementara itu identitas syariah yang digaungkan melalui hijab syar'i sebagai wacana gaya berpakaian ideal bagi perempuan muslim juga merupakan kuasa kapitalisme dalam produk fashion. Hijab syar'i yang merupakan konstruksi dari figur publik yang memproduksi wacana ke-islaman melalui gaya berpakaian mereka, menjadi dominasi atas maraknya produksi pasar atas fashion tersebut. Modalitas para figur publik tersebut ditijau dari persfektif Bourdieu (1996) bahwa wacana yang berkembang dan menjadi masif melalui ketokohan figur tersebut seakan diterima sebagai sesuatu yang ideal. Dan relasi antara yang memproduksi wacana dan penerima wacana, menjadikan figur tersebut sebagai tolok ukur atas 
wacana yang mendominasi. Salah satunya melalui hijab syar'i yang digaungkan melalui figur-figur aktor film-film Islami.

Dengan beredarnya wacana hijab syar'i tersebut, kapitalisme dari produsen fashion mulai merambah pangsa pasar masyarakat muslim. Syariah kembali menjadi selubung dominasi atas kapitalisme produk fashion yang beberapa produknya bisa dikatakan tidak sesuai dengan gaya berpakaian yang sesuai hukum Islam yang sewajarnya, dan lebih mengarah pada tata laku berlebihan dalam berhias (Tabarruj). Contohnya produk hijab punuk unta, hijab gaya ninja, dan beberapa produk fashion yang jika digunakan justru menonjolkan penampilan lekuk tubuh perempuan. Wacana syariah yang sedemikian masif menjadi basis profit kapitalis yang dengan identitas syariah yang diwacanakan atas produk mereka.

Syariah dalam konteks hijab syar'i ini menjadikan praktik konsumsi atas produk fashion sebagai identitas mereka yangmenunjukkan kesalihan, padahal praktik tersebut merupakan konstruksi dari wacana yang menggerogoti masyarakat muslim menjadi konsumtif, dan semakin melanggengkan kapitalisme. Meskipun ada yang berdalih bahwa desain produk hijab syar'i ada juga yang langsung dari desainer muslim sendiri, justru itu merupakan kapitalisme baru yang muncul dari masyarakat muslim sendiri, lalu dengan produk tersebut menjadi legitimasi untuk mewacanakan konsep ideal dalam gaya berpakaian.

\section{F. WACANA SYARIAH SEBAGAI INDUSTRI BUDAYA ISLAMI}

Dominasi dari Dewan Syariah Nasional (DSN) sebagai gate keeper atas kesesuaian hukum dan ciri Islami atas suatu produk atau program tertentu, semakin memasifkan wacana syariah sebagai praktik konsumsi atas identitas keIslaman dan kesalihan. Gokariksel dan Mclarney (2010) dalam artikelnya Muslim Women, consumer capitalism, and the Islamic culture industry, menyebutkan bahwa praktik-praktik konsumsi atas komoditas yang digaungkan melalui motif agama merupakan konstruksi identitas sebagai individu atau komunitas yang Islami. Dalam hal ini juga Gokariksel mendiskusikan fenomena boomingnya hijab sebagai komoditas yang berkembang secara global.

Hijab dari produksi kapitalisme mulai merambah masyarakat muslim untuk mengakomodasi kebutuhan ekspresif mereka akan kesalihan. Selain itu juga wacana kecantikan dan ke-feminim-an melalui hijab menjadikan kapitalisme yang 
mengejar profit semakin langgeng dengan ekspresi identitas ke-Islaman, terutama yang menyasar perempuan muslim (Gokariksel \& McLarney, 2010)

Praktik industri budaya dalam wacana syariah ini merupakan upaya rasionalisasi atas logika agama untuk mengontrol proses-proses tertentu sebagai bagian dari identitas masyarakat muslim. Syariah tidak hanya selubung atas identitas, akan tetapi membentuk kapitalisme baru dalam masyarakat muslim itu sendiri, salah satunya melalui bank syariah, Koperasi syariah, Hijab syar'i yang digaungkan, merupakan mode-mode kapitalisme yang menjajal masyarakat muslim untuk profit yng lebih besar melalui konsumsi wacana kesalihan atas produk syariah tersebut.

Hegemoni wacana syariah ditinjau dari pemikiran Gramsci (1999) bahwa syariah yang dihajatkan sebagai solusi, justru membentuk dominasi baru dalam masyarakat muslim sendiri yang tidak sesuai dengan hukum dalam Islam. Peran intelektual Islam dalam hal ini yang direpresentasikan melalui Dewan Syariah Nasional tidak lain hanyalah sebagai pihak yang melegitimasi bahwa syariah yang digaungkan sudah sesuai dengan hukum yang dipahami dengan interpretasi mereka. padahal sebenarnya legitimasi mereka sebagai pihak yang mengkonstruksi wacana syariah masih terbuka lebar peluang untuk dikritisi agar sesuai dengan nilai-nilai Islami dan sosialisme untuk sesama manusia.

\section{G. SIMPULAN}

Apa yang menjadi tujuan utama dalam wacana syariah sebenarnya merupakan upaya emansipatoris agar masyarakat muslim menjembatani asas-asas hukum agama dalam praktiknya. Akan tetapi ketika wacana syariah bertemu dengan kapitalisasi produk/program, itulah yang membuat syariah dalam praktiknya mulai dipertimbangkan nilai-nilai profit sebagai tujuan. Contoh dalam ekonomi Islam, asas syariah yang dikembangkan seharusnya diakomodasi melalui zakat mal (Harta) dan infaq dalam bentuk Baitul Mal yang menjadi sentral pengelolaan keuangan yang Islami. Dan untuk menjembatani usaha-usaha masyarakat muslim tanpa bunga yang menjerat di awal, akan tetapi dengan adanya biaya administratif yang dikeluarkan ketika usaha individu atau kelompok berjalan dengan baik.

Logika kesadaran untuk saling menolong dalam syariat Islam itulah yang sejalan dengan nilai sosialisme. Sosialisme untuk sesama manusia sebagai bentuk penghormatan atas syariat Islam bisa tertuang dalam upaya membangun 
kesejahteraan bersama melalui praktik ekonomi yang sewajajarnya untuk dikembangkan oleh bank-bank syariah tersebut. Akan tetapi disebabkan asas kapitalis mereka yang cukup berperan dalam perusahaan, justru sosialisme itu benar-benar terabaikan, yang ada hanya kepentingan profit atas kapitalisme mereka.

Lalu dalam wacana wisata syariah, Hotel Syariah dan hijab syar'i tersebut, yang berperan benar-benar upaya konsumtif atas komoditas sebagai konstruksi identitas atas keber-agamaan (religiusitas). Hijab syar'i yang menjadi trend diproduksi massal oleh kapitalis dan membentuk wacana baru atas kesalihan, kecantikan, akan tetapi tetap fashionable (stylish). Produk fashion yang berkembang pun menjadi wacana yang dikonstruksi melalui kuasa figur publik melalui media untuk menjadikan tolok ukur idealnya gaya berpakaian yang Islami dari konsumsi komoditas fashion tersebut. Imbasnya keuntungan yang dikejar kaum kapitalis semakin termediasi dengan upaya untuk memenuhi kebutuhan ekspresif masyarakat muslim melalui produk fashion tersebut.

Sementara wisata syariah dan hotel syariah merupakan selubung untuk menegaskan identitas ke-Islaman, meskipun pada praktiknya masih perlu tinjauan lebih dalam atas konsep-konsep yang ditawarkan. Justru wisata syariah dalam hal ini menjadi objek privatisasi dari pemilik kuasa yang menjadi legitimasi atas praktik-praktik teralienasinya penduduk pribumi dari wilayah mereka. Begitu juga dengan hotel syariah, identitas yang dilekatkan masih diperlukan evaluasi lebih jauh supaya identitas tersebut memang sesuai dengan hukum Islam, dan akomodatif untuk kembalinya markah masyarakat muslim pada hal-hal progresif dalam memperjuangkan eksistensinya dalam peradaban.

Identitas syariah hanyalah sebagai wacana yang menjadi selubung atas dominasi dan selubung kapitalisme yang menguasai masyarakat muslim, namun diterima sebagai sesuatu yang taken for granted (sewajarnya) melalui kuasa dari Dewan Syariah Nasional yang berperan sebagai pihak intelektual atas masifnya hegemoni wacana tersebut. Lalu upaya emansipatoris untuk penyadaran bahwa rasionalitas instrumental melalui produk budaya yang diselubungi identitas syariah tersebut adalah sesuatu yang syarat dengan kepentingan, mestinya dikembalikan dengan akar syariat atau hukum Islam yang sesuai dengan nilai-nilai sosialisme yang sangat dijunjung tinggi dalam Islam. Salah satunya nilai kebermanfaatan untuk sesama manusia, dengan tujuan kesejahteraan bersama. 


\section{DAFTAR PUSTAKA}

Bourdieu, Pierre. 1996. Distinction : a social critique of the judgement of taste . Cetakan ke-8, translated by Richard Nice. Cambridge. Harvard University Press.

Foucault, Michel. 2002. Wacana : Kuasa/Pengetahuan. Yogyakarta : Bentang Budaya.

Gokariksel, Banu \& Ellen McLarney. 2010. Muslim Women, consumer capitalism, and the Islamic culture industry. Journal Middle East of Woman Studies (JMEWS), Duke University.

Horkheimer, Max \& Theodore W. Adorno. 2002. Dialektika Pencerahan. Yogyakarta : IRCiSoD

http://Islamwiki.blogspot.co.id/2012/08/pengertian-syariah-dalam-arti-luasdan.html?m=1

http://kabarlombok.com/potensi-wisata-syariah-yang-kian-bertumbuh/

http://travel.kompas.com/read/2016/02/08/210700227/Lombok.Destinasi.Wisata.H alal.Terbaik.Dunia.

Patria, Nezar. 1999. Antonio Gramsci: Negara \& Hegemoni. Yogyakarta : Pustaka Pelajar.

Wattimena, Reza AA. 2012. Berpikir Kritis bersama Pierre Bourdieu. (online). (diakses dari http://rumahfilsafat.com/2012/04/14/sosiologi-kritis-dansosiologi-reflektif-pemikiran-pierre-bourdieu/

Sarwat, Ahmad. 2013, dalam http://www.rumahfiqh.com/x.php/id=1383143419

Halimatusa'diah. 2015. Etnisitas Dan Agama Dalam Kontestasi Wacana Kekuasaan Di Media Baru. LIPI : Jurnal Masyarakat dan Budaya, volume 17 No. 2 Tahun 2015.

Barker, Chris. (2004). Cultural Studies Teori dan Praktik. Yogyakarta: Kreasi Wacana.

Aziz, Jamal Abdul .2012. Perbankan Syariah Di Indonesia (Telaah Kritis Terhadap Islamisasi Sistem Perbankan). E-journal UIN Sunan Kalijaga, Yogyakarta. 